\title{
Pengaruh Karakteristik Wirausaha Dan Pemilihan Lokasi Usaha Terhadap Keberhasilan Usaha Dikampung Macuan Distrik Masni Kabupaten Manokwari
}

\author{
Desy Intan Pematasari Suriana ${ }^{1}$, Makarius Bajari ${ }^{2}$, Louis S. Bopeng ${ }^{3}$ \\ ${ }^{1}$ Alumni Jurusan Manajemen, Universitas Papua \\ ${ }^{2,3}$ Dosen Jurusan Manajemen, Universitas Papua
}

Received: September 2021; Accepted: September 2021; Published: September 2021

\begin{abstract}
Abstrak
Karakteristik wirausaha dan pemilihan lokasi usaha merupakan faktor-faktor yang mendorong tercapainya keberhasilan usaha. Penelitian ini bertujuan untuk menganalisis pengaruh karakteristik wirausaha dan pemilihan lokasi usaha terhadap keberhasilan usaha kios sembako di Kampung Macuan Distrik Masni Kabupaten Manokwari. Jenis pendekatan penelitian menggunakan pendekatan kuantitatif. Populasi yang digunakan dalam penelitian adalah seluruh wirausaha kios sembako dengan jumlah 46 responden. Teknik pengambilan sampel menggunakan sampel jenuh. Data yang digunakan dalam penelitian adalah data primer dan data sekunder. Teknik pengumpulan data menggunakan kuesioner, sedangkan analisis data menggunakan analisis regresi linear berganda. Hasil penelitian menunjukkan bahwa secara parsial karakteristik wirausaha berpengaruh signifikan terhadap keberhasilan usaha, pemilihan lokasi usaha berpengaruh signifikan terhadap keberhasilan usaha, dan secara simultan karakteristik wirausaha dan pemilihan lokasi usaha berpengaruh signifikan terhadap keberhasilan usaha. Beberapa hal yang perlu diperhatikan oleh wirausaha mencakup percaya diri, berani mengambil risiko, berorientasi masa depan, lokasi usaha yang strategis dan sering dilalui banyak transportasi umum.
\end{abstract}

Kata kunci: karakteristik wirausaha, pemilihan lokasi usaha, dan keberhasilan usaha

\section{Abstract}

Entrepreneurial characteristics and business location selection are factors that encourage the achievement of business success. This study aims to analyze the effect of entrepreneurial characteristics and business location selection on the success of a basic food stall business in Macuan Village, Masni District, Manokwari Regency. This type of research approach uses a quantitative approach. The population used in the study were all food stall entrepreneurs with a total of 46 respondents. The sampling technique used a saturated sample. The data used in this study are primary data and secondary data. The data collection technique used a questionnaire, while the data analysis used multiple linear regression analysis. The results show that partially entrepreneurial characteristics have a significant effect on business success, business location selection has a significant effect on business success, and simultaneously entrepreneurial characteristics and business location selection have a significant effect on business success. Some things that need to be considered by entrepreneurs include being confident, willing to take risks, future-oriented, strategic business locations and frequent public transportation.

Keywords:entrepreneurial characteristics, business location selection, and business success 
How to Cite: Suriana, D.I.P., Bajari, M., Bopeng, L.S., (2021). Pengaruh Karakteristik Wirausaha Dan Pemilihan Lokasi Usaha Terhadap Keberhasilan Usaha Dikampung Macuan Distrik Masni Kabupaten Manokwari. JFRES: Journal of Fiscal and Regional Economy Studies, 4(2), 15 - 26.

\footnotetext{
Corresponding author:

E-mail: louis.bopeng@gmail.com
}

\section{PENDAHULUAN}

Pada saat sekarang ini bisnis di Indonesia telah mengalami kemajuan yang sangat pesat. Baik bisnis dengan skala besar maupun bisnis skala kecil. Dalam bisnis skala besar maupun skala kecil banyak pertimbangan yang perlu di perhatikan agar bisnis tersebut berhasil. Salah satu contoh bisnis skala kecil adalah usaha mikro kecil di bidang dagang ataupun jasa. Usaha mikro kecil sekarang ini telah tersebar luas di berbagai daerah di Indonesia. Hal ini membuat persaingan antar usaha mikro kecil semakin ketat. Persaingan dalam suatu usaha tentunya harus di sertai dengan adanya upaya wirausahawan menerapkan strategi persaingan untuk mencapai tujuan usaha.

Wirausahawan atau enterpreuner adalah seseorang yang berperan dalam melakukan aktivitas usaha. Wirausahawan memiliki tujuan agar usaha yang dijalankan mencapai keberhasilan. Untuk mencapai keberhasilan yang ditargetkan, suatu usaha harus mempunyai berbagai cara demi mempertahankan kelangsungan hidup usaha yang dijalankan. Keberhasilan setiap usaha pun berbeda-beda tergantung dari masing-masing wirausahawan. Wirausahawan biasanya melakukan investasi di berbagai macam sektor. Seperti dengan membuka usaha mikro kecil, di sektor dagang, sektor jasa, dan industri lainnya. Sikap cerdas, kreatif, memiliki rasa ingin tahu yang tinggi, dan mengikuti perkembangan teknologi modern, dapat di terapkan dalam diri wirausahawan sehingga dapat menciptakan keberhasilan usaha. Keberhasilan usaha di pengaruhi oleh beberapa faktor yaitu kemampuan, kemauan, serta tekad dan berkerja keras. Selain faktor-faktor tersebut, dalam mencapai keberhasilan usaha juga didukung dengan adanya karakteristik wirausaha dan pemilihan lokasi usaha.

Karakteristik wirausaha secara umum menggambarkan keunikan personal atau psikologis seseorang yang terdiri dari nilai sikap, watak dan kebutuhan. Karakteristik yang sangat umum yaitu memiliki jiwa kreativitas dan kepemimpinan, inovatif, percaya diri, memiliki etika yang baik, keinginan untuk berprestasi, keinginan mengambil resiko dan berorientasi ke masa depan. Hal ini di dukung oleh penelitian Purwanti (2012) dalam Vijaya dan Irwansyah (2017) yang menyatakan bahwa wirausahawan membutuhkan karakter/watak (karakteristik wirausaha) yang tertanam dalam dirinya masingmasing sehingga memberikan dampak terhadap perkembangan atas usaha yang dikelola. Karakteristik wirausaha merupakan keinginan akan suatu keberhasilan/kesuksesan, keinginan mengambil resiko yang wajar, optimis, dan berkeinginan untuk menjalankan suatu usaha/bisnis.Selain karakteristik wirausaha, hal penting lainnya yang menjadi pendukung dalam tercapainya keberhasilan usaha adalah pemilihan lokasi usaha.

Lokasi usaha merupakan tempat untuk melakukan kegiatan dalam suatu bisnis. Lokasi akan mempengaruhi posisi suatu usaha dalam persaingan dan menentukan kelangsungan hidup usaha. Lokasi yang mudah di jangkau akan lebih sering di kunjungi pelanggan. Kesalahan dalam memilih lokasi usaha dapat menimbulkan dampak buruk bagi usaha yang di jalankan. Karena pemilihan lokasi usaha merupakan modal dan langkah awal yang sangat menentukan kesuksesan pada usaha yang di kelola.

Kesalahan-kesalahan dalam karakteristik wirausaha dan pemilihan lokasi usaha dapat menimbulkan dampak buruk terhadap usaha, sehingga hal ini dapat menimbulkan masalahmasalah berupa kerugian hingga kebangkrutan. Masalah-masalah itulah yang akan di hadapi oleh wirausahawan ketika tidak memperhatikan hal-hal yang perlu di pertimbangkan dalam memulai suatu usaha. Kesalahan yang muncul ketika menjalankan suatu usaha biasanya antara lain karena kurangnya pengetahuan dan pengalaman tentang bisnis, kurangnya 
pemahaman tentang karakter seorang wirausaha serta memilih lokasi awal yang kurang strategis untuk usahanya.

Dalam penelitian ini yang akan dijadikan fokus penelitian adalah wirausaha kios sembako dikampung Macuan. Menurut Kamus Besar Bahasa Indonesia kios adalah toko kecil. Sedangkan sembako (sembilan bahan pokok) menurut Keputusan Menteri Perindustrian dan Perdagangan Nomor 115/MPP/Kep/2/1998 merupakan sembilan jenis kebutuhan pokok masyarakat. Sembilan bahan pokok tersebut meliputi : Beras (ataupun pengganti beras misalnya sagu, jagung, singkong dll), gula pasir, garam, telur ayam, daging (yang mencakup ayam, ikan, daging sapi, kambing dll), sayuran dan buah-buahan, minyak goreng (margarine, mentega), susu, Gas LPG (termasuk minyak tanah).

Kampung Macuan terletak antara kampung Wasegi Indah yang terletak di bagian Selatan, Kampung Makwan yang terletak di bagian Barat, Kampung Aimasi yang terletak di bagian Timur, dan Kampung Prafi Barat yang terletak di bagian Utara Kampung Macuan. Berdasarkan data Kampung Macuan 2020, sesuai dengan SK Transmigrasi Kampung Macuan memiliki luas sebesar 1.300 Hektar dengan jumlah penduduk sebanyak 2.203 orang. Sebagian penduduk di kampung Macuan bermata pencaharian sebagai petani, kuli bangunan dan juga berwirausaha dengan membuka kios sembako.

Penelitian ini bertujuan untuk melihat apakah terdapat pengaruh karakteristik wirausaha terhadap keberhasilan usaha, pengaruh pemilihan lokasi usaha terhadap keberhasilan usaha, kemudian pengaruh secara simultan karakteristik wirausaha dan pemilihan lokasi usaha terhadap keberhasilan usaha dikampung Macuan Distrik Masni Kabupaten Manokwari. Hasil penelitian ini diharapkan dapat digunakan oleh wirausaha kios sembako di Kampung Macuan sebagai salah satu dasar pertimbangan pengambilan keputusan dalam memulai suatu usaha/bisnis.

\section{METODE PENELITIAN}

Penelitian ini menggunakan pendekatan kuantitatif dengan jenis masalah asosiatif. Penelitian ini dilakukan pada wirausaha kios sembako di Kampung Macuan Distrik Masni Kabupaten Manokwari.

Metode pengambilan sampel yang digunakan dalam penelitian ini adalah metode non probability sampling. Teknik yang digunakan untuk menentukan sampel adalah sampel jenuh. Sampel yang digunakan dalam penelitian ini yaitu sebanyak 46 responden.

Teknik pengumpulan data yaitu dengan observasi, kuesioner dan wawancara yang ditujukan kepada wirausaha kios sembako di Kampung Macuan Distrik Masni Kabupaten Manokwari.

Teknik analisis data yang digunakan dalam penelitian ini, yaitu antara lain:

\section{Uji Validitas}

Uji validitas dilakukan untuk mengukur suatu data valid atau tidak. Validitas adalah pernyataan sampai sejauh mana data-data yang ditampung pada suatu kuesioner dapat mengukur apa yang ingin diukur (Putu Agung, 2012). Dalam penelitian ini pengujian validitas menggunakan teknik korelasi pearson product moment. Hasil uji validitas dapat diukur dengan melihat nilai $r$. Apabila $r_{\text {hitung }}>r_{\text {tabel}}$, maka dapat dikatakan valid. Begitu pula sebaliknya, apabila $r_{\text {hitung }}<r_{\text {tabel }}$, maka dapat dikatakan tidak valid (Ghozali, 2005).

\section{Uji Reliabilitas}

Reliabilitas menunjukkan apakah instrumen tersebut secara konsisten memberikan hasil ukuran yang sama tentang sesuatu yang diukur pada waktu yang berlainan (Putu Agung, 2012). Suatu kuesioner dikatakan reliabel jika jawaban seseorang terhadap pertanyaan itu konsisten dari waktu ke waktu. Dalam penelitian ini menggunakan uji cronbach alpha yaitu suatu kuesioner di katakan reliabel apabila nilai alpha $>0,60$ (Ghozali, 2005).

\section{Uji Asumsi Klasik}

\section{a) Uji Normalitas}

Uji normalitas bertujuan apakah dalam model regresi, variabel pengganggu atau residual memiliki distribusi normal. Untuk melihat normalitas residual adalah dengan melihat grafik histogram yang membandingkan antara data observasi dan data histogram, yaitu dengan melihat normal probability plot yang 
membandingkan distribusi kuantitatif dari distribusi normal (Ghozali, 2005).

\section{b) Uji Multikolonearitas}

Menurut Yudiaatmaja (2013) untuk mendeteksi ada atau tidaknya multikolonieritas, dapat diketahui dari nilai tolerance dan variance inflation factor (VIF) masing-masing variabel independen. Dalam menentukan ada atau tidaknya multikolonieritas dapat diketahui dengan kriteria sebagai berikut:

a. Jika nilai VIF $>10$ atau jika nilai tolerance $<$ 0,10 maka ada multikolonieritas dalam model regresi.

b. Jika nilai $\mathrm{VIF}<10$ atau jika nilai tolerance $>$ 0,10 maka tidak ada multikolonieritas dalam model regresi.

\section{c) Uji Heteroskedastisitas}

Untuk mendeteksi ada atau tidaknya heteroskedasitas, dapat melihat grafik plot antara nilai prediksi variabel terkait (dependen) yaitu ZPRED dengan residunya SRESID. Deteksi ada tidaknya heteroskedasitas dapat dilakukan dengan melihat ada tidaknya pola tertentu pada grafik scatterplot antara SRESID dan ZPRED dimana sumbu $\mathrm{Y}$ adalah $\mathrm{Y}$ yang telah diprediksi, dan $\mathrm{X}$ adalah residual ( $\mathrm{Y}$ prediksi $-\mathrm{Y}$ sesungguhnya) yang telah di-studentized (Ghozali, 2018).

\section{Uji Regresi Linear Berganda}

Metode analisis data yang digunakan dalam penelitian ini yaitu metode analisis regresi linear berganda. Regresi linear berganda di gunakan untuk mengukur kekuatan hubungan antara variabel atau lebih menunjukkan arah hubungan antara variabel dependen dengan independen (Ghozali, 2009).

Persamaan yang digunakan adalah sebagai berikut :

$\mathrm{Y}=\alpha+\beta 1 \mathrm{X} 1+\beta 2 \mathrm{X} 2+\mathrm{e}$

Keterangan :

$\mathrm{Y}=$ Keberhasilan usaha

$\alpha=$ Nilai konstan

$\beta_{1}=$ Koefisien variabel karakteristik wirausaha

$\beta_{2}=$ Koefisien variabel pemilihan lokasi usaha

$\mathrm{X}_{1}=$ Karakteristik wirausaha

$\mathrm{X}_{2}=$ Pemilihan lokasi usaha

$\mathrm{e}=$ Standart error

\section{Uji Parsial (Uji t)}

Jika t menunjukkan seberapa jauh pengaruh satu variabel penjelas/independen secara individual dalam menerangkan variasi variabel dependen (Ghozali, 2013).

a. Jika $t_{\text {hitung }}<\mathrm{t}_{\text {tabel, }}$, atau signifikan $\mathrm{t}>0,05$ maka $\mathrm{H}_{0}$ diterima dan $\mathrm{H}_{\mathrm{a}}$ ditolak artinya tidak berpengaruh signifikan.

b. Jika $t_{\text {hitung }}>\mathrm{t}_{\text {tabel}}$, atau signifikan $\mathrm{t}<0,05$ maka $\mathrm{H}_{0}$ ditolak dan $\mathrm{H}_{\mathrm{a}}$ diterima artinya berpengaruh signifikan.

\section{Uji Simultan (Uji F)}

Uji simultan (Uji F) adalah uji yang digunakan untuk mengetahui semua variabel independen atau bebas yang di masukkan dalam model mempunyai pengaruh secara bersama-sama terhadap variabel dependen atau variabel terkait (Ghozali, 2005). Untuk menguji hipotesis di gunakan statistik $\mathrm{F}$ dengan pengambilan keputusan sebagai berikut :

a. Jika $\mathrm{F}_{\text {hitung }}<\mathrm{F}_{\text {tabel, }}$, atau nilai signifikan $\mathrm{F}>$ 0,05 maka $\mathrm{H}_{0}$ diterima dan $\mathrm{H}_{\mathrm{a}}$ di tolak yang berarti tidak ada pengaruh yang signifikan antar variabel $X$ secara bersama-sama terhadap variabel $\mathrm{Y}$.

b. Jika $\mathrm{F}_{\text {hitung }}>\mathrm{F}_{\text {tabel, }}$, atau nilai signifikan $\mathrm{F}<$ 0,05 maka $\mathrm{H}_{0}$ ditolak dan $\mathrm{H}_{\mathrm{a}}$ diterima, maka terdapat pengaruh yang signifikan antar variabel $X$ secara bersama-sama terhadap variabel Y.

\section{HASIL PENELITIAN}

\section{Deskripsi Data}

\section{Karakteristik Responden Berdasarkan Jenis Kelamin}

Karakteristik responden dalam penelitian ini berdasarkan jenis kelamin dapat dilihat pada tabel 1. di bawah ini:

Tabel 1. Karakteristik Responden Berdasarkan Jenis Kelamin

\begin{tabular}{lcc}
\hline Jenis Kelamin & Frekuensi & $\begin{array}{c}\text { Persentase } \\
(\%)\end{array}$ \\
\hline Laki-laki & 8 & 17 \\
\hline Perempuan & 38 & 83 \\
\hline Total & 46 & 100 \\
\hline
\end{tabular}

Sumber: Data diolah, 2020 
Berdasarkan Tabel 1, dapat diketahui karakteristik responden berdasarkan jenis kelaminnya. Dari 46 orang responden wirausaha kios sembako di Kampung Macuan, sebanyak 38 orang responden dengan persentase sebesar $(83 \%)$ adalah responden dengan jenis kelamin perempuan dan sisanya sebanyak 8 orang responden dengan persentase sebesar (17\%) adalah responden dengan jenis kelamin laki-laki.

Dapat di simpulkan bahwa, dalam penelitian ini responden dengan jenis kelamin perempuan lebih dominan sebagai wirausaha kios sembako di Kampung Macuan. Berdasarkan hasil penelitian, hal ini karena rata-rata perempuan yang tinggal di Kampung Macuan lebih berminat menjadi wirausaha di bandingkan lakilaki. Selain sebagai ibu rumah tangga, berwirausaha juga memberikan penghasilan untuk membantu keuangan keluarga dalam mencukupi kebutuhan ekonomi sehari-hari.

\section{Karakteristik Responden Berdasarkan Usia}

Karakteristik responden dalam penelitian ini berdasarkan usia dapat dilihat pada tabel 2 berikut:

Tabel 2. Karakteristik Responden Berdasarkan Usia

\begin{tabular}{ccc}
\hline Usia (Tahun) & Frekuensi & Persentase (\%) \\
\hline $20-25$ & 2 & 4 \\
\hline $26-30$ & 6 & 13 \\
\hline $31-35$ & 11 & 24 \\
\hline $36-40$ & 6 & 13 \\
\hline $41-45$ & 5 & 11 \\
\hline $46-50$ & 16 & 35 \\
\hline Total & 46 & 100 \\
\hline
\end{tabular}

\section{Sumber: Data diolah, 2020}

Berdasarkan Tabel 2, dapat diketahui karakteristik responden berdasarkan usianya. Dari 46 orang responden yang merupakan wirausaha kios sembako di Kampung Macuan, dengan jumlah paling banyak dari responden yang berusia 46-50 yaitu sebanyak 16 orang responden dengan persentase sebesar (35\%), responden berusia 31-35 tahun yaitu sebanyak 11 orang responden dengan persentase sebesar (24\%), responden berusia 26-30 tahun yaitu sebanyak 6 orang responden dengan persentase sebesar (13\%), responden berusia 36-40 tahun yaitu sebanyak 6 orang responden dengan persentase sebesar (13\%), responden berusia 4145 tahun yaitu sebanyak 5 orang responden dengan persentase sebesar $(11 \%)$, dan responden berusia 20-25 tahun yaitu sebanyak 2 orang responden dengan persentase sebesar (4\%). Sehingga dapat di simpulkan bahwa mayoritas responden dalam penelitian ini adalah berusia 46-50 tahun. Hal ini karena pada usia tersebut responden telah memasuki usia produktif. Usia produktif yaitu usia dimana seseorang mampu bekerja untuk mencukupi kebutuhan hidupnya. Rentang usia ini adalah 15-64 tahun.

\section{Karakteristik Responden Berdasarkan Tingkat Pendidikan}

Karakteristik responden dalam penelitian ini berdasarkan tingkat pendidikan dapat dilihat pada tabel 3 berikut:

Tabel 3. Karakteristik Responden Berdasarkan Tingkat Pendidikan

\begin{tabular}{lcc}
\hline $\begin{array}{c}\text { Tingkat } \\
\text { Pendidikan }\end{array}$ & Frekuensi & $\begin{array}{c}\text { Persentase } \\
(\%)\end{array}$ \\
\hline SMP & 10 & 22 \\
\hline SMA & 25 & 54 \\
\hline Sarjana & 3 & 7 \\
\hline Total & 46 & 100 \\
\hline
\end{tabular}

Sumber: Data diolah, 2020

Berdasarkan Tabel 3, dapat diketahui karakteristik responden berdasarkan tingkat pendidikannya. Dari 46 orang responden yang merupakan wirausaha kios sembako di Kampung Macuan, dengan jumlah paling banyak dari responden berpendidikan SMA yaitu sebanyak 25 orang responden dengan persentase sebesar (54\%), kemudian responden berpendidikan SMP yaitu sebanyak 10 orang responden dengan persentase sebesar (22\%) responden berpendidikan SD yaitu sebanyak 8 orang responden dengan persentase sebesar (17\%), dan responden berpendidikan Sarjana yaitu sebanyak 3 orang responden dengan persentase sebesar (7\%). Sehingga dapat disimpulkan bahwa mayoritas wirausaha di Kampung Macuan berpendidikan SMA. Hal ini karena dalam membangun dan memulai suatu usaha pendidikan juga diperlukan, agar pengalaman serta pengetahuan yang di peroleh dapat di implementasikan dalam usaha yang dijalankan sehingga memberikan pengaruh positif untuk tercapainya tujuan usaha.

\section{Hasil Uji Validitas}

Hasil uji validitas dalam penelitian ini disajikan dalam tabel 4. 
Tabel 4. Hasil Uji Validitas

\begin{tabular}{|c|c|c|c|c|}
\hline Variabel & Nomor Pernyataan & r rhitung & $\mathbf{r}_{\text {tabel }}$ & Keterangan \\
\hline \multirow{13}{*}{ Karakteristik Wirausaha $\left(\mathrm{X}_{1}\right)$} & $\mathrm{X} 1-01$ & 0,385 & 0,2907 & Valid \\
\hline & $\mathrm{X} 1-02$ & 0,552 & 0,2907 & Valid \\
\hline & $\mathrm{X} 1-03$ & 0,524 & 0,2907 & Valid \\
\hline & X1-04 & 0,560 & 0,2907 & Valid \\
\hline & $\mathrm{X} 1-05$ & 0,511 & 0,2907 & Valid \\
\hline & $\mathrm{X} 1-06$ & 0,533 & 0,2907 & Valid \\
\hline & X1-07 & 0,567 & 0,2907 & Valid \\
\hline & $\mathrm{X} 1-08$ & 0,416 & 0,2907 & Valid \\
\hline & X1-09 & 0,523 & 0,2907 & Valid \\
\hline & $\mathrm{X} 1-10$ & 0,564 & 0,2907 & Valid \\
\hline & $\mathrm{X} 1-11$ & 0,335 & 0,2907 & Valid \\
\hline & $\mathrm{X} 1-12$ & 0,555 & 0,2907 & Valid \\
\hline & $\mathrm{X} 1-13$ & 0,570 & 0,2907 & Valid \\
\hline \multirow[t]{8}{*}{ Pemilihan Lokasi Usaha $\left(\mathrm{X}_{2}\right)$} & $\mathrm{X} 2-01$ & 0,635 & 0,2907 & Valid \\
\hline & $\mathrm{X} 2-02$ & 0,624 & 0,2907 & Valid \\
\hline & $\mathrm{X} 2-03$ & 0,513 & 0,2907 & Valid \\
\hline & $\mathrm{X} 2-04$ & 0,648 & 0,2907 & Valid \\
\hline & $\mathrm{X} 2-05$ & 0,508 & 0,2907 & Valid \\
\hline & $\mathrm{X} 2-06$ & 0,409 & 0,2907 & Valid \\
\hline & X2-07 & 0,429 & 0,2907 & Valid \\
\hline & X2-08 & 0,406 & 0,2907 & Valid \\
\hline \multirow[t]{9}{*}{ Keberhasilan Usaha (Y) } & Y-01 & 0,510 & 0,2907 & Valid \\
\hline & $\mathrm{Y}-02$ & 0,751 & 0,2907 & Valid \\
\hline & $\mathrm{Y}-03$ & 0,703 & 0,2907 & Valid \\
\hline & $\mathrm{Y}-04$ & 0,578 & 0,2907 & Valid \\
\hline & $\mathrm{Y}-05$ & 0,613 & 0,2907 & Valid \\
\hline & Y-06 & 0,560 & 0,2907 & Valid \\
\hline & Y-07 & 0,681 & 0,2907 & Valid \\
\hline & Y-08 & 0,594 & 0,2907 & Valid \\
\hline & Y-09 & 0,542 & 0,2907 & Valid \\
\hline
\end{tabular}

Sumber: Data diolah, 2020

Dari hasil uji validitas, dapat dilihat bahwa semua nilai $r_{\text {hitung }}$ untuk setiap pernyataan kuesioner pada variabel karakteristik wirausaha $\left(\mathrm{X}_{1}\right)$, pemilihan lokasi usaha $\left(\mathrm{X}_{2}\right)$ dan keberhasilan usaha (Y) memperlihatkan nilai yang lebih besar dari nilai $r_{\text {tabel }}$ yaitu 0,2907 $\left(\mathrm{r}_{\text {hitung }}>\mathrm{r}_{\text {tabel }}\right)$, sehingga dapat di simpulkan bahwa semua pernyataan kuesioner pada variabel $\mathrm{X}$ maupun $\mathrm{Y}$ dinyatakan valid.

\section{Hasil Uji Reliabilitas}

Hasil uji reliabilitas menunjukkan bahwa pada setiap variabel menghasilkan nilai cronbach's alpha $>0,60$. Dengan ini, dapat disimpukan bahwa semua pernyataan kuesioner pada variabel karakteristik wirausaha (X1), pemilihan lokasi usaha (X2), dan keberhasilan usaha (Y) dinyatakan reliabel.
Tabel 5. Hasil Uji Reliabilitas

\begin{tabular}{lll}
\hline $\begin{array}{l}\text { Variabel } \\
\text { Penelitian }\end{array}$ & $\begin{array}{l}\text { Nilai } \\
\text { Cronbach's } \\
\text { Alpha }\end{array}$ & Keterangan \\
\hline $\begin{array}{l}\text { Karakteristik } \\
\text { Wirausaha (X1) }\end{array}$ & 0,754 & Reliabel \\
\hline $\begin{array}{l}\text { Pemilihan } \\
\text { Lokasi Usaha } \\
\text { (X2) }\end{array}$ & 0,601 & Reliabel \\
\hline $\begin{array}{l}\text { Keberhasilan } \\
\text { Usaha (Y) }\end{array}$ & 0,788 & Reliabel \\
\hline
\end{tabular}

\section{Sumber: Data diolah, 2020}

\section{Hasil Uji Asumsi Klasik}

\section{1) Hasil Uji Normalitas}

Hasil uji normalitas dalam penelitian ini menggunakan uji normalitas one sample kolmogorov-smirnov dengan melihat nilai 
Asymp. Sig. (2-tailed) $>5 \%(0,05)$ dan dengan melihat gambar grafik P-P Plot sebagai berikut:

Tabel 6. Hasil Uji Normalitas One Sample Kolmogorov-Smirnov

\begin{tabular}{llr}
\hline & & \multicolumn{1}{c}{$\begin{array}{c}\text { Unstandardized } \\
\text { Residual }\end{array}$} \\
\hline $\mathrm{N}$ & & $\begin{array}{r}46 \\
\text { Normal Parameters }\end{array}$ \\
Most Extreme Differences & Mean & .0000000 \\
& Std. Deviation & 1.96927390 \\
& Absolute & .121 \\
Test Statistic & Positive & .050 \\
Asymp. Sig. (2-tailed) & Negative & -.121 \\
a. Test distribution is Normal. & & .121 \\
b. Calculated from data. & & $.091^{\mathrm{c}}$ \\
c. Lilliefors Significance Correction. & & \\
\hline Sumber: Data diolah, 2020 & & \\
\hline
\end{tabular}

\section{Sumber: Data diolah, 2020}

Dari hasil uji ini, dapat diketahui bahwa nilai signifikansi Asymp. Sig. (2-tailed) pada uji normalitas One-Sample Kolmogorov-Smirnov adalah sebesar $0,091>0,05$. Dengan demikian disimpulkan bahwa data yang digunakan dalam penelitian berdistribusi secara normal sehingga memenuhi syarat pengujian regresi linear berganda.

2) Hasil Uji Multikolonearitas

Dari hasil uji multikolinearitas (Tabel 7), menunjukan bahwa variabel karakteristik wirausaha $\left(\mathrm{X}_{1}\right)$ mempunyai nilai $V I F$ sebesar 1,472 dan nilai Tolerance sebesar 0,679. Variabel pemilihan lokasi $\left(\mathrm{X}_{2}\right)$ mempunyai nilai VIF sebesar 1,472 dan nilai Tolerance sebesar 0,679 .

Nilai $V I F$ pada kedua variabel independen $<10$ dan nilai Tolerance $>0,10$. Maka dapat disimpulkan bahwa seluruh variabel yang digunakan pada penelitian ini tidak ada gejala multikolonieritas sehingga memenuhi syarat pengujian regresi linear berganda.

Tabel 7. Coefficients

\begin{tabular}{|c|c|c|c|c|c|c|c|c|}
\hline & \multirow[t]{2}{*}{ Model } & \multicolumn{2}{|c|}{$\begin{array}{l}\text { Unstandardized } \\
\text { Coefficients }\end{array}$} & \multirow{2}{*}{$\begin{array}{c}\text { Standardized } \\
\text { Coefficients } \\
\text { Beta }\end{array}$} & \multirow[t]{2}{*}{$\mathbf{T}$} & \multirow[t]{2}{*}{ Sig. } & \multicolumn{2}{|c|}{ Collinearity Statistics } \\
\hline & & B & Std. Error & & & & Tolerance & VIF \\
\hline I & (Cor & 2.376 & 5.631 & & .422 & .675 & & \\
\hline & Karakteristik & .415 & .108 & .509 & 3.852 & .000 & .679 & 1.472 \\
\hline & Pemilihan Lokasi Usaha & .367 & 179 & .271 & 2.053 & .046 & .679 & 1.472 \\
\hline
\end{tabular}

a. Dependent Variable: Keberhasilan Usaha

Sumber: Data diolah, 2020

Tabel 8. Hasil Uji Heteroskedastisitas Glejser

\begin{tabular}{|c|c|c|c|c|c|}
\hline \multirow[t]{2}{*}{ Model } & \multicolumn{2}{|c|}{ Unstandardized Coefficients } & \multirow{2}{*}{$\begin{array}{c}\begin{array}{c}\text { Standardized } \\
\text { Coefficients }\end{array} \\
\text { Beta }\end{array}$} & \multirow[t]{2}{*}{$\mathbf{t}$} & \multirow[t]{2}{*}{ Sig. } \\
\hline & B & Std. Error & & & \\
\hline (Constant) & .629 & 3.120 & & .202 & .841 \\
\hline Karakteristik Wirausaha & .070 & .060 & .213 & 1.171 & .248 \\
\hline Pemilihan Lokasi Usaha & -.087 & .099 & -.160 & -.880 & .384 \\
\hline
\end{tabular}

\section{a. Dependent Variable: ABS_RES}

Sumber: Data diolah, 2020

\section{3) Hasil Uji Heteroskedastisitas}

Dari hasil uji heteroskedastisitas glejser, terlihat bahwa variabel karakteristik wirausaha (X1) mempunyai nilai signifikansi sebesar 0,248 dan variabel pemilihan lokasi (X2) mempunyai nilai signifikansi sebesar 0,384 . Nilai signifikansi pada kedua variabel independen menunjukkan nilai yang $>0,05$ (Sig. $>0,05)$. Sehingga dapat disimpulkan bahwa tidak terjadi heteroskedastisitas pada model regresi sehingga 
memenuhi syarat pengujian regresi linear berganda.

\section{Hasil Uji Regresi Linear Berganda}

Analisis regresi linear berganda yang dipakai dalam penelitian ini bertujuan untuk menguji pengaruh karakteristik wirausaha dan pemilihan lokasi usaha terhadap keberhasilan usaha pada kios sembako di Kampung Macuan. Dari hasil uji pada tabel 7, didapatkan model persamaan regresi linear berganda yaitu sebagai berikut:

$\mathrm{Y}=2,376+0,415 \mathrm{X} 1+0,367 \mathrm{X} 2+\mathrm{e}$

Berdasarkan persamaan regresi linear berganda di atas dapat diinterpretasikan sebagai berikut :

1. Nilai konstan tersebut adalah 2,376. Menyatakan bahwa apabila variabel independen yang terdiri atas karakteristik wirausaha $\left(\mathrm{X}_{1}\right)$ dan pemilihan lokasi usaha $\left(\mathrm{X}_{2}\right)$ jika di anggap konstan, maka keberhasilan usaha bernilai yaitu 2,376.

2. Variabel karakteristik wirausaha $\left(X_{1}\right)$ memiliki koefisien regresi sebesar 0,415. Nilai koefisien regresi positif menunjukkan bahwa karakteristik wirausaha memiliki pengaruh positif terhadap keberhasilan usaha di Kampung Macuan. Artinya, semakin baik karakteristik wirausaha, maka akan semakin baik pula keberhasilan usaha yang akan di peroleh wirausahakios sembako di Kampung Macuan.

3. Variabel pemilihan lokasi usaha $\left(\mathrm{X}_{2}\right)$ memiliki koefisien regresi sebesar 0,367. Nilai koefisien regresi positif menunjukkan bahwa pemilihan lokasi usaha memiliki pengaruh positif terhadap keberhasilan usaha di Kampung Macuan. Artinya, semakin baik pemilihan lokasi usaha, maka akan semakin baik pula keberhasilan usaha yang akan di peroleh wirausaha kios sembako di Kampung Macuan.

\section{Hasil Uji Parsial (Uji t)}

Hasil uji hipotesis atau uji $\mathrm{t}$ antara variabel independen yaitu karakteristik wirausaha dan pemilihan lokasi usaha terhadap variabel dependen yaitu terhadap keberhasilan usaha pada wirausaha kios sembako yang ada di Kampung Macuan di sajikan pada tabel 7.

Dari hasil uji parsial ( $\mathrm{t}$ ) diatas, diperoleh nilai $\mathrm{t}_{\text {hitung }}$ pada variabel karakteristik wirausaha $\left(\mathrm{X}_{1}\right)$ sebesar 3,852 dengan tingkat signifikansi sebesar 0,000 dan nilai $t_{\text {hitung }}$ pada variabel pemilihan lokasi $\left(\mathrm{X}_{2}\right)$ sebesar 2,053 dengan signifikansi sebesar 0,046 . Hal ini menunjukan bahwa nilai thitung pada kedua variabel independen lebih besar dari nilai tabel $(3,852$ dan $2,053>2,017)$ dan nilai signifikansi pada kedua variabel independen memiliki angka $<0,05$ $(0,000$ dan $0,046<0,05)$. Dengan demikian, dapat disimpulkan bahwa secara parsial karakteristik wirausaha dan pemilihan lokasi usaha berpengaruh signifikan terhadap keberhasilan usaha pada wirausaha kios sembako di Kampung Macuan.

\section{Hasil Uji Simultan (Uji F)}

Hasil uji hipotesis atau uji $F$ antara variabel independen yaitu karakteristik wirausaha dan pemilihan lokasi usaha terhadap variabel dependen yaitu terhadap keberhasilan usaha pada wirausaha kios sembako di Kampung Macuan disajikan dalam tabel 9.

Tabel 9. Hasil Uji Hipotesis Simultan (Uji F)

\begin{tabular}{lrrrrr}
\hline \multicolumn{1}{c}{ Model } & Sum of Squares & Df & Mean Square & F & Sig. \\
\hline Regression & 167.401 & 2 & 83.701 & 20.624 & $.000^{\mathrm{b}}$ \\
\hline Residual & 174.512 & 43 & 4.058 & & \\
\hline Total & 341.913 & 45 & & & \\
\hline a. Dependent Variable: Keberhasilan Usaha & \multicolumn{5}{l}{} \\
\hline b. Predictors: (Constant), Pemilihan Lokasi Usaha, Karakteristik Wirausaha \\
\hline
\end{tabular}

Sumber: Data diolah, 2020

Dari hasil uji simultan (F), didapatkan nilai $\mathrm{F}$ hitung sebesar 20,624 dengan signifikansi sebesar 0,000 . Hal ini menunjukan bahwa nilai $F$ hitung lebih besar dari nilai $\mathrm{F}$ tabel $(20,624>$ $3,214)$ dan nilai signifikansi memiliki angka <
$0,05(0,000<0,05)$. Dengan demikian, dapat disimpulkan bahwa $\mathrm{H}_{0}$ ditolak dan $\mathrm{H}_{\mathrm{a}}$ diterima yang artinya secara simultan atau bersama-sama karakteristik wirausaha $\left(\mathrm{X}_{1}\right)$ dan pemilihan lokasi usaha $\left(\mathrm{X}_{2}\right)$ berpengaruh signifikan 
terhadap keberhasilan usaha (Y) pada wirausaha kios sembako di Kampung Macuan.

\section{Pembahasan}

\section{1) Karakteristik Wirausaha}

Hasil analisis hipotesis secara parsial (Uji t) menunjukkan bahwa karakteristik wirausaha $\left(\mathrm{X}_{1}\right)$ memiliki pengaruh signifikan terhadap keberhasilan usaha (Y), dengan nilai signifikansi lebih kecil dari $0,05(0,000<0,05)$. Hal ini menggambarkan bahwa semakin banyak diterapkannya karakteritik wirausaha dalam diri wirausahawan, maka akan semakin tinggi keberhasilan usaha yang akan diperoleh pada kios sembako di Kampung Macuan. Hasil penelitian diatas sejalan dengan penelitian yang di lakukan oleh Jumaedi (2012) yang menyatakan bahwa adanya pengaruh karakteristik wirausaha terhadap keberhasilan usaha (Studi Kasus Pada Pengusaha Kecil Di Pekalongan) dan penelitian yang dilakukan oleh Pradana (2019) yang menyatakan bahwa adanya pengaruh karakteristik wirausaha terhadap keberhasilan usaha pada petani lele di Kota Madiun.

Variabel karakteristik wirausaha memiliki 6 indikator yang digunakan untuk mengetahui seberapa besar pengaruh variabel karakteristik wirausaha terhadap keberhasilan usaha kios sembako di Kampung Macuan. Berdasarkan jawaban responden pada kuesioner diperoleh jawaban paling tinggi pada indikator berorientasi pada tugas dan hasil dengan jumlah 798. Dari hasil jawaban responden tersebut, dapat diketahui bahwa berorientasi pada tugas dan hasil merupakan hal yang sangat penting. Orientasi menurut KBBI adalah peninjauan untuk menentukan sikap (arah, tempat, dan sebagainya) yang tepat dan benar. Tugas-tugas yang dimiliki oleh wirausaha dan menjadi tanggungjawabnya perlu diselesaikan secara tepat dan baik, dengan begitu hasil yang diperoleh pun akan baik sehingga sesuai dengan tujuan wirausaha pada kios sembako di Kampung Macuan. Kemudian jawaban paling terendah terdapat pada indikator keorisinilan dengan jumlah 191. Dari hasil jawaban responden tersebut, dapat diketahui bahwa keorisinilan memiliki pengaruh yang kecil dalam karakteristik wirausaha pada kios sembako di Kampung Macuan.
Keorisinilan dalam konteks disini maksudnya seseorang yang tidak meniru orang lain, tetapi memiliki pendapat sendiri, memiliki ide yang murni dari dirinya sendiri, serta memiliki kemampuan melakukan sesuatu. Meskipun memiliki pengaruh yang kecil, keorisinilan perlu menjadi perhatian karena keorisinilan dapat menjadi salah satu ciri khas yang dimiliki oleh suatu usaha, seperti lebih menerapkan ide-ide yang kemudian dapat diimplementasikan ke dalam usaha yang dikelola berupa bagaimana wirausaha dalam menghadapi konsumen, wirausaha dalam penataan produk yang ditawarkan, sehingga dapat menarik konsumen untuk membeli, kemudian wirausaha dalam menghadapi pesaing, bagaimana wirausaha dapat mempertahankan usahanya melalui caracara yang diterapkan. Bukan dengan menjatuhkan pesaing, tetapi cara-cara tersebut dapat berupa ide-ide dari wirausaha itu sendiri untuk menjaga dan mempertahankan kelangsungan hidup usahanya agar berkembang dan berhasil, sehingga dapat terus bersaing dengan usaha-usaha di bidang yang sama.

Hal-hal tersebut di atas membuktikan bahwa sangat pentingnya karakteristik wirausaha yang harus di miliki oleh setiap wirausahawan yang ada di Kampung Macuan, agar usaha yang dijalankan dapat mencapai keberhasilan usaha di masa-masa mendatang sesuai dengan tujuannya.

\section{2) Pemilihan Lokasi Usaha}

Hasil analisis hipotesis secara parsial (Uji t) menunjukkan bahwa pemilihan lokasi usaha $\left(\mathrm{X}_{2}\right)$ memiliki pengaruh signifikan terhadap keberhasilan usaha $(\mathrm{Y})$, dengan nilai signifikansi lebih kecil dari $0,05(0,046<0,05)$. Hal ini menggambarkan bahwa semakin baik dalam pemilihan lokasi usaha, maka akan semakin baik pula keberhasilan usaha yang akan diperoleh pada kios sembako di Kampung Macuan. Hasil penelitian ini sejalan dengan penelitian yang di lakukan oleh Fu'ad (2015) membuktikan bahwa faktor-faktor yang diteliti dalam pemilihan lokasi usaha mempunyai pengaruh terhadap kesuksesan usaha/ keberhasilan usaha di komplek Shopping Centre Jepara.

Variabel pemilihan lokasi usaha memiliki 4 indikator yang digunakan untuk mengetahui seberapa besar pengaruh variabel pemilihan 
lokasi usaha terhadap keberhasilan usaha kios sembako di Kampung Macuan. Berdasarkan jawaban responden pada kuesioner diperoleh jawaban paling tinggi pada indikator ketersediaan lahan parkir dengan jumlah 768 .

Dengan tersedianya lahan parkir yang luas, tentunya akan memberikan dampak baik terhadap konsumen maupun wirausahawan. Konsumen akan lebih aman ketika sedang berbelanja, aman dari segi pencurian dan aman dari segi keselamatannya. Yang kemudian hal itu akan memunculkan keinginan konsumen untuk kembali berbelanja pada wirausaha tersebut. Sedangkan untuk wirausahawan, lahan parkir yang luas dapat digunakan untuk menjalankan kegiatan usahanya, untuk kelancaran transaksi jual beli maupun kelancaran aktivitas kendaraan perusahaan yang membawa persediaan barangbarang yang akan ditawarkan.

Kemudian jawaban paling terendah terdapat pada indikator lokasi pasar dilalui banyak transportasi umum dengan jumlah 192. Dari hasil jawaban responden tersebut, dapat diketahui bahwa indikator lokasi pasar dilalui banyak transportasi umum memiliki pengaruh yang kecil terhadap keberhasilan usaha di Kampung Macuan. Meskipun memiliki pengaruh yang kecil, hal tersebut perlu diperhatikan, karena pada dasarnya ketika banyak transportasi umum yang melalui tempat usaha pastinya akan banyak konsumen yang datang untuk berbelanja.

Tetapi di Kampung Macuan hanya sebagian kios yang dilalui transportasi umum, karena letak kios-kios di Kampung Macuan tidak seluruhnya berada di depan jalan raya atau jalan poros yang sering dilalui oleh transportasi umum. Sebagian kios-kios sembako di Kampung Macuan terletak di dalam kompleks atau jalur, yang terbagi atas beberapa jalur yaitu jalur Barat dan jalur Timur. Sehingga kios-kios yang terletak di dalam kompleks atau jalur sangat strategis bagi konsumen maupun masyarakat yang bertempat tinggal di sekitar kios tersebut. Maka dari itu, pemilihan lokasi usaha sangat penting sebagai pertimbangan ketika akan memulai suatu usaha. Pemilihan lokasi usaha selain sebagai asset, juga sebagai modal awal terbentuknya keberhasilan usaha pada usaha yang dikelola.

\section{3) Keberhasilan Usaha}

Hasil hipotesis secara simultan (Uji F) menunjukkan bahwa karakteristik wirausaha $\left(\mathrm{X}_{1}\right)$ dan pemilihan lokasi usaha $\left(\mathrm{X}_{2}\right)$ memiliki pengaruh signifikan terhadap keberhasilan usaha (Y), dengan nilai signifikansi lebih kecil dari $0,05(0,000<0,05)$. Hal ini menggambarkan bahwa karakteristik wirausaha dan pemilihan lokasi usaha merupakan hal penting yang perlu diperhatikan untuk mencapai keberhasilan usaha pada kios sembako di Kampung Macuan.

Hasil penelitian ini sejalan dengan penelitian yang dilakukan oleh Nisa (2017) yang menyatakan bahwa faktor-faktor yang mempengaruhi keberhasilan usaha meliputi lokasi usaha, skiil atau kemampuan, karakteristik wirausaha, dan motivasi berpengaruh signifikan terhadap keberhasilan usaha pada UMKM rendang di Kota Payakumbuh.

Berdasarkan jawaban responden terhadap 5 indikator keberhasilan usaha, jawaban pada kuesioner paling tinggi diperoleh pada indikator terbangunnya citra baik dengan jumlah 413 . Citra merupakan gambaran yang ada dalam benak publik (konsumen) tentang perusahaan (wirausaha) menyangkut pelayanannya, kualitas produk, perilaku perusahaan atau individu di dalam perusahaan dan lainnya, yang pada akhirnya persepsi ini akan mempengaruhi sikap konsumen apakah akan mendukung atau sebaliknya (Kriyantono, 2008).

Dengan terbangunnya citra baik berupa kepercayaan dalam suatu usaha, akan memberikan dampak positif seperti lebih banyakknya konsumen yang akan berbelanja pada usahanya bahkan memberikan kepercayaan dan bisa menjadi konsumen tetap pada usaha tersebut. Sehingga usaha tersebut menjadi semakin maju dan berkembang.

Kemudian jawaban responden dengan nilai paling rendah terdapat pada indikator laba (keuntungan) dengan jumlah 188. Dari hasil jawaban responden tersebut dapat diketahui bahwa laba (keuntungan) menjadi indikator dengan pengaruh paling kecil dalam keberhasilan usaha pada kios sembako di Kampung Macuan.

Laba (keuntungan) memiliki pengaruh kecil bukan berarti suatu wirausaha tidak memperhatikan laba yang diperoleh, tetapi 
wirausaha di Kampung Macuan menganggap bahwa citra baik perusahaan menjadi hal yang penting pada usahanya. Maka itu, citra baik menjadi indikator yang paling tinggi pengaruhnya.

Dengan citra baik yang telah terbangun, secara langsung konsumen akan berbelanja secara terus menerus pada usahanya. Dengan begitu laba akan diperoleh dan perputaran jual beli akan semakin cepat. Sehingga dapat di lihat bahwa citra baik suatu usaha dan laba (keuntungan) merupakan dua hal yang saling berkaitan, dengan semakin terbangunnya citra baik akan memberikan dampak positif berupa semakin banyaknya laba (keuntungan) yang akan diperoleh.

\section{KESIMPULAN}

1. Berdasarkan hasil dan pembahasan tentang pengaruh karakteristik wirausaha dan pemilihan lokasi usaha terhadap keberhasilan usaha di kampung Macuan maka dapat di simpulkan bahwa :

2. Terdapat pengaruh Karakteristik Wirausaha (X1) secara parsial terhadap Keberhasilan Usaha (Y) di kampung Macuan. Hal ini di tunjukkan dengan nilai signifikan lebih kecil dari $0,05(0,000<0,05)$ berdasarkan hasil tersebut maka H1 diterima yang berarti variabel karakteristik wirausaha berpengaruh terhadap keberhasilan usaha.

3. Terdapat pengaruh Pemilihan Lokasi Usaha (X2) secara parsial terhadap Keberhasilan Usaha (Y) di kampung Macuan. Hal ini di tunjukkan dengan nilai signifikan lebih kecil dari $0,05(0,046<0,05)$ berdasarkan hasil tersebut maka H2 diterima yang berarti variabel pemilihan lokasi usaha berpengaruh terhadap keberhasilan usaha.

4. Tedapat pengaruh Karakteristik Wirausaha (X1) dan Pemilihan Lokasi Usaha (X2) secara simultan terhadap Keberhasilan Usaha (Y) di kampung Macuan. Hal ini di tunjukkan dengan nilai signifikan sebesar 0,000 lebih kecil dari $0,05(0,000<0,05)$ berdasarkan hasil tersebut maka $\mathrm{H} 3$ diterima yang berarti variabel karakteristik wirausaha dan pemilihan lokasi usaha secara simultan berpengaruh terhadap keberhasilan usaha.

\section{REKOMENDASI}

Berdasarkan hasil pembahasan penelitian dan kesimpulan maka saran dari peneliti yang dapat di berikan adalah sebagai berikut :

\section{Bagi Wirausaha}

Studi ini di harapkan dapat menambah wawasan, pengetahuan serta pengalaman bagi wirausaha kios sembako di Kampung Macuan sebaiknya memiliki karakter orisinalitas yang tidak meniru ide orang lain, kemudian memiliki ide-ide inovatif sendiri yang dapat diterapkan dalam usahanya misalnya ide kreatif dalam penjualan dan mempromosikan produk, kemudian melakukan pembaruan produk-produk yang ditawarkan agar konsumen tidak merasa bosan berbelanja di tempat usahanya serta menghadapi konsumen maupun pesaing dengan hubungan yang positif untuk dapat menghasilkan keuntungan yang di inginkan.

Selain itu wirausaha sebaiknya perlu menerapkan keberanian dalam pengambilan resiko dan mempunyai tantangan. Pengambilan resiko yang wajar misalnya wirausaha perlu mengeluarkan sejumlah uang untuk membangun usahanya, mengorbankan waktu dan tenaganya untuk menjalankan dan mengelola usaha, serta resiko dan tantangan dalam menghadapi ketidakpastian pembelian di kios sembako Kampung Macuan.

Diharapkan bagi wirausaha untuk memperhatikan pemilihan lokasi usaha sebaiknya lokasi usaha banyak dilalui oleh transportasi umum serta lokasi usaha strategis bagi konsumen yang berada disekitar usaha tersebut karena banyaknya konsumen yang melakukan pembelian tergantung dari pemilihan lokasi usaha, selain strategis untuk konsumen yang bertempat tinggal di Kampung Macuan juga di harapkan strategis untuk konsumen yang berasal dari luar wilayah kampung Macuan.

Keberhasilan dalam suatu usaha dapat dilihat dari perkembangan usaha dan besarnya penghasilan. Di harapkan wirausaha kios sembako di Kampung Macuan perlu mengukur seberapa besar penghasilan yang di dapatkan agar wirausaha dapat mengetahui apakah usahanya mendapatkan keuntungan atau tidak, sehingga wirausaha akan lebih mudah untuk menentukan arah usaha mereka. 
Hal itu dapat berupa lebih banyaknya jenis produk yang ditawarkan, meningkatkan kualitas produk, memperluas usahanya, merekrut karyawan baru dan lainnya. Selain itu diharapkan adanya persaingan yang sehat antar wirausaha kios sembako di Kampung Macuan karena setiap konsumen bebas untuk memilih di kios mana mereka berbelanja, maka dari itu halhal yang menjadi saran bagi wirausaha tersebut perlu di terapkan dengan baik untuk tercapainya keberhasilan usaha.

\section{Bagi penelitian selanjutnya}

Penelitian selanjutnya dapat menggunakan atau menambahkan variabel-variabel bebas lainnya di luar model penelitian ini. Misalnya Modal Usaha, Kreativitas Usaha atau Inovasi Usaha sehingga dapat memberikan penjelasan yang lebih lengkap mengenai apa saja yang mempengaruhi keberhasilan usaha dengan objek penelitian yang berbeda. Selain itu melakukan penelitian dengan menggunakan sampel yang lebih besar yang dapat mewakili populasi penelitian, sehingga akan lebih menambah konsistensi dan pengetahuan yang lebih luas dari hasil penelitiannya.

\section{DAFTAR PUSTAKA}

Fu'ad, E. N. (2015). Pengaruh Pemilihan Lokasi terhadap Kesuksesan Usaha Berskala Mikro/Kecil di Kompleks Shopping Centre Jepara, Journal. Universitas Islam Nahdlatul Jepara.
Ghozali, I. (2018). Aplikasi Analisis Multivariate Dengan Program SPSS. Semarang: Badan Penerbit Universitas Diponegoro.

Jumaedi, H. (2012). Hubungan karakteristik wirausaha terhadap keberhasilan usaha (studi kasus pada pengusaha kecil di Pekalongan). Manajerial: Jurnal Manajemen dan Sistem Informasi, 11(2), 13-19.

Kriyantono, Rachmat. 2008. Public Relation writing Media Public Relations Membangun Citra Korporat. Jakarta: Kencana.

Nisa, R. (2017). Analisis Faktor-Faktor yang Mempengaruhi Keberhasilan Usaha (Studi pada UMKM Rendang di Payakumbuh), Jurnal. Universitas Andalas.

Putu Agung, A. A. (2017). Metodologi Penelitian Bisnis. Malang: UB Press.

Pradana, A. E. (2019). Pengaruh Karakteristik Wirausaha terhadap Keberhasilan Usaha pada Petani Lele di Kota Malang, Jurnal. Universitas PGRI Madiun.

Vijaya, D. P. (2017). Pengaruh Modal Psikologi, Karakteristik Wirausaha, Modal Usaha dan Staregi Pemasaran terhadap Perkembangan Usaha UMKM di Kecamatan Buleleng Tahun 2017, Jurnal. Singaraja : Universitas Pendidikan Ganesha.

Yudiaatmaja, F. (2013). Analisis Regresi dengan Menggunakan Aplikasi Statistik SPSS . Jakarta: PT Gramedia Pustaka Utama. 